\title{
Beyond a Genealogy of Human Rights Introduction to a Discussion Forum
}

\author{
IVO CERMAN
}

General histories of human rights have become quite popular recently. Suffice it to say that while I was working on this discussion forum, one more big history of human rights was published, and several more are being prepared. ${ }^{1}$ There is an upsurge of scholarly interest in this topic, there is a lot of energy invested in it, but in which direction should this energy be channeled? In what follows, I will first try to explain the situation which prompted me to organize this forum, and secondly, provide a summary of Dan Edelstein's new book On the Spirit of Rights, which is the subject of our comments. ${ }^{2}$

Unfortunately, the field has been dominated by two prolific American authors who tend towards extremely simplistic views, which present, I believe, a dangerous obstacle to a free exploration of the early history of human rights in the Age of Enlightenment. This is not to deny that Jonathan Israel helped to rehabilitate intellectual history and that Samuel Moyn recalled the significance of Jimmy Carter's human rights campaign, but the interpretative frameworks behind these achievements are rather reductive, to say the least. Whereas Jonathan Israel with his atheism-oriented interpretation ${ }^{3}$ has found respect but no imitators, Samuel Moyn, with his insistence on the „breakthrough moment" in the 1970s, ${ }^{4}$ did find several followers among historians of the twentieth century. ${ }^{5}$ This new chronology goes hand in hand with a silent reshuffling of human rights

1 Vincenzo Ferrone, The Enlightenment and the Rights of Man, Oxford 2019 (This is a translation of idem, Storia dei diritti dell' nomo, Rome 2014); earlier global histories include Micheline Ishay, Human Rights. From Ancient Times to Globalization Era, Berkeley 2004; Eike Wolgast, Geschichte der Menschen- und Bürgerrechte, Stuttgart 2009; Francisco Javier Ansuátegui Roig - José Manuel Rodríguez Uribes (edd.), Historia de los derechos fundamentales, Madrid 1998-2013, 22 vols.; Rhona K. M. Sмit h, The Textbook of International Human Rights, Oxford 2016, pp. 5-24. See also Ivo CerMAN, Illusions and Realism in the History of Human Rights, Opera historica 17, 2016, pp. 249-270.

2 Dan Edelstein, On the Spirit of Rights, Chicago 2019.

3 Starting in 2001, J. Israel has published a series of seven thick books on the subject. Most recently Jonathan Israel, The Enlightenment that Failed. Ideas, Revolutions and Democratic Defeat 1748-1830, Oxford 2019, pp. 290-318 (on human rights) and IDEM, The Expanding Blaze: How the American Revolution Ignited the World 1775-1848, Princeton-Oxford 2017.

4 See Samuel Moyn, The Last Utopia. Human Rights in History, Cambridge, MA, 2010; IDEM, Die neue Historiographie der Menschenrechte, Geschichte und Gesellschaft 38, 2012, pp. 545-572. The most recent of Moyn's four books on the subject is IDEM, Not Enough. Human Rights in an Unequal World, Cambridge, MA, 2018.

5 These include Stefan Ludwig Hofmann, Jan Eckel, Sarah B. Snyder, Arieh Neyer, Debbie Sharnack and others, whose work is characterized by a narrow focus on the post-1945 world, highlighting the significance of non-state entities, and a shared vocabulary. Samuel Moyn has also started his own 
from the realm of law into the realm of utopian thought. ${ }^{6}$ Whereas law operates with norms providing rules to regulate human behavior now, utopian thought sets ideals to be attained in the future and invites people to follow the principle that the end justifies the means. Genuine human rights are supposed to be „a transnational ideal and movement“, and the earlier rights were - in Moyn's opinion - ,part of the authority of the state, not invoked to transcend it“. 7 They were tied to national states and not to transnational organizations and therefore do not belong to the genealogy of human rights.

With a bold Machtspruch, the early modern history of human rights has been declared irrelevant. The "genealogy“ or „links" of international human rights, as Moyn calls it, reach back only to the 1970 s. ${ }^{8}$ This is obviously appealing for many people. Activists and lawyers are now relieved of the uncomfortable feeling that they advocate ideas coined by eighteenth-century „dead white men“ (or even slaveholders). ${ }^{9}$ The uncomfortable Enlightenment past may be disposed of. I am afraid that a similar bundle of motives explains why the "breakthrough-moment thesis“ is also attractive to historians of the post-1945 world. Compared with earlier histories of human rights written by lawyers, Moyn even managed to do without the content of the UN Bill of Rights, the UN treaty system, or other legal documents. ${ }^{10}$ In his conception, it took only pure hearts and utopian goals to find the real human rights. Narrowly-focused historians of human rights, such as Jan Eckel, may now ignore the remote past and delicate juridical thought of obnoxious legal thinkers such as Hans Kelsen or even Robert Alexy and focus on personalized histories of one single utopian decade, carefully purged of Communist human

series, „Human Rights in History“ (with Cambridge UP). The general editors are Stefan Ludwig Hofmann and Moyn himself.

6 Another utopian conception has been proposed by Benjamin Gregg (Austin University, Texas) who dreams of a „human rights state“. See René Wolfsteller - Benjamin GregG, Realistic Utopia? Critical Analyses of the „Human Rights State", Theory and Deployment, The International Journal of Human Rights 21, 2017, pp. 219-229 (a special topic issue).

7 S. Moyn, The Last Utopia, p. 7.

8 Ibidem, pp. 19-21; idem, On the Genealogy of Morals, The Nation, April 17, 2007.

9 On these labels see Gordon S. Wood, Revolutionary Characters. What Made the Founders Different, New York 2006, pp. 3-28. In 2017 there was also a movement demanding the removal of Jefferson monuments in Charlettosville, VA, and in Washington, D.C., because he was held to be a racist, a rapist and a slaveholder. For a recent example of a non-historian embracing the breakthrough perspective see Rhoda E. Howard-Hassmann, Review of „Not Enough. Human Rights in an Unequal World by Samuel Moyn“, Human Rights Quarterly 41, 2019, pp. 515-527.

10 This sort of scholarship took the UN Bill of Human Rights (or just the UDHR) as its starting point and reconstructed the history of human rights as developments leading up to its individual articles. See Louis Hen kin, The Rights of Man Today, Boulder 1978; Idem, The Age of Rights, New York 1990; Jack Donnelly, Universal Human Rights in Theory and Practice, Boulder 1989; Paul Gordon Lauren, The Evolution of International Human Rights. Visions Seen, Philadelphia 1998. 
rights concepts, of German far-left extremism, of Palestinian terrorism, of the Khmers Rouges or of the utopian Jonestown massacre. ${ }^{11}$

The other problem is the lure of writing history of human rights merely as a filiation of isolated terms, as a genealogy, without reading the texts and exploring the legal contexts. ${ }^{12}$ Usually it is supported by highly problematic n-grams of the long-term sequences of human-rights terms which are used to prove the exceptional character of the 1970s. The temptation of simple solutions is strong, which explains why there is considerably less interest in more intricate contextual interpretations produced by other American historians of human rights, such as Brian Tierney. ${ }^{13}$

However, it is not the aim of this editorial introduction to discuss the interpretations of Jonathan Israel and Samuel Moyn in depth, this has been already done by others, and without any effect, ${ }^{14}$ we wish to consecrate this forum to the discussion of another American historian, who has featured in recent debates as an intelligent critic and conversation partner for both of them, and who has now produced a highly challenging interpretation of his own. ${ }^{15}$ This is Dan Edelstein of the University of Stanford, California, and his monograph On the Spirit of Rights published in 2019. ${ }^{16}$

The book, as I understand it, seeks to rehabilitate the significance of the Enlightenment era for the history of human rights. The stated aim of Edelstein's succinct account

11 See Jan Eckel, The Ambivalence of Good. Human Rights in International Politics since the 1940s, Oxford 2019 (originally Die Ambivalenz des Guten. Menschenrechte in der Internationalen Politik seit den 1940ern, Göttingen 2014). Even though the author appreciates also the merits of post-1945 activists, the focus of this huge book is actually on the campaign against Pinochet's Chile and the 1970s. For similar narrowly-focused histories of the utopian decade see Aryeh NeIER, The International Human Rights Movement: A History, Princeton 2012; Barbara J. Keyes, Reclaiming American Virtues. The Human Rights Revolution of the 1970s, Cambridge, MA, 2014; Sarah B. SNyder, Human Rights Activism and the End of the Cold War, Cambridge 2011.

12 The focus on isolated terms has an obvious parallel in the German Begriffsgeschichte, see Hans JoAs, Die Sakralität der Person. Eine neue Genealogie der Menschenrechte, Berlin 2011 (translation The Sacredness of the Person. A New Genealogy of Human Rights, Washington, D.C., 2013).

13 Brian Tierney, The Idea of Natural Rights. Studies on Natural Rights, Natural Law, and Church Law 1150-1625, Cambridge 2001 (2nd edition); IDEM, Liberty and Law. The Idea of Permissive Natural Law, 1100-1800, Washington, D.C., 2014. See I. Cerman, Illusions and Realism, pp. 259-262.

14 Israel has met criticism mainly in France from Enlightenment experts; Moyn has met only mild criticism. For my reflections on J. Israel see Ivo Cerman, Evropské osvicenství Jonathana Israele, Cornova 1,2011, pp. 27-50; IDEM, Introduction: Enlightenment in Bohemia, in: idem - Rita Krueger - Susan Reynolds (edd.), The Enlightenment in Bohemia, Oxford 2011, pp. 1-36, especially pp. 2-3; on S. Moyn IDem, Illusions and Realism, pp. 263-267.

15 On Jonathan Israel see Dan Edelstein, A response to Israel, in: Kate E. Tunstall (ed.), Self-Evident Truths? Human Rights and the Enlightenment, Oxford 2012, pp. 127-137; on S. Moyn and L. Hunt see IDEm, Enlightenment Rights Talk, The Journal of Modern History 86, 2014, pp. 530-555.

16 Dan Edelstein, On the Spirit of Rights, Chicago 2019. 
is to reconstruct the genealogy of the rights regimes enshrined in the Virginia Declaration of 1776 and the French Declaration of the Rights of Man of $1789 .{ }^{17}$ "Regimes“ are something like larger frameworks or argumentative units. It is a term he applies to distinguish between a particular concept and the way in which it was used to build up an argument. ${ }^{18}$ Basically, he is interested in the genealogy of a rhetorical model, in which rights serve as "trumps" that citizens may use against the state. The trump metaphor has been borrowed from Ronald Dworkin. ${ }^{19}$ Edelstein distinguishes an abridgment regime, a transfer regime and a preservation regime. Whereas in the abridgment regime citizens were supposed to renounce their rights after entering the civil state, in the transfer regime the state took over the guarantee of their rights. Adherents of the abridgment regime were mostly absolutist thinkers, whereas the transfer regime was preferred by republican-leaning authors. It was only in the preservation regime that rights were used as trumps and citizens were believed to retain their rights even after leaving the state of nature. For this reason, the declarations were thinkable only after the victory of the preservation regime. Edelstein's chief concern is not to find the „breakthrough moment“, but to reconstruct the process in which the preservation regime won over the other two.

In geographical terms, his focus is on France, North America and Great Britain. The long-term development then appears as an exchange of ideas between France, on the one side, and the two countries of English common-law culture on the other. Edelstein does provide a discussion of common law culture, Blackstone and the „natural constitutionalism" that grew out of it, but does not discuss Jeremy Bentham and his critique of the French declarations. In France he follows the transition from a preparatory „rightstalk" to binding documents. In doing so, he notices differences between the political-legal cultures of both areas. In North America, natural rights were used to express the liberties the colonists had known from the common law in new terms. It was the legacy of these peculiar liberties protected by courts that helped them to appreciate natural rights as individual rights. In their final form, in the Bill of Rights of 1789/91, the rights were purged of their natural rights talk and reduced to entitlements that came from the English common law tradition.

In France, the interlude of seventeenth-century absolutism weakened the memory of sixteenth-century notion of individual rights and replaced it with a collective conception of "droits nationaux" which saw the whole nation as the bearer of rights and as a collective existing even before the social contract. As inheritors of a completely different legal culture, the French were then pinning their hopes not on liberties protected by courts, but on a prospective system of laws. Even though Edelstein does not subscribe to Lynn Hunt's claim about the key role of sentimental novels and feelings, he does not support

17 D. Edelstein, On the Spirit, p. 1.

18 IвIDEM, p. 2.

19 Imidem, p. 4, 16-17, 53. See Ronald Dworkin, Taking Rights Seriously, Cambridge, MA, 1077, p. 6. 
the significance of natural law theories either. ${ }^{20}$ Knowing that secular natural law did not take hold at universities in France, he attributes the key role to the economic school of physiocrats. ${ }^{21}$

At a specific juncture in the second half of the eighteenth century, there was a slight increase in the intensity of rights talk, plus the advancement of physiocratic thinking coupled with interest in Stoic natural order and free market economy. Atheism or stronger religious skepticism were not a part of this juncture because all these ideas were still set within a theistic framework. There was also a revival of Roman law, which helped to advance the idea of freedom for slaves and abolition of slavery. It helped to see that "law of nations", which provided a juridical justification of enslavement of war captives, should not be conflated with natural law, which held, in its original Roman form, that slavery is contrary to the law of nature (ius naturale). This was the situation in which the French declaration of 1789 originated. The look at the debate in the National Assembly shows that the deputies were torn between the collective notion of rights of the nation and the notion of rights of individuals. Even after the promulgation of the declaration of 1789, the French were still more interested in holding the nation together than upholding individual rights and their declaration therefore included provisions for future laws that would be issued to realize the newly enshrined rights. This légicentrisme, was fundamentally different from North American common law liberties. The political-legal cultures behind the terms were so different that we may consider the human rights terminologies in both countries as faux amis. The last chapter responds to current debates by sketching further developments to the UDHR of 1948 and shows that the Enlightenment was an important stage in this process because it consolidated the preservation regime.

In terms of method, Edelstein does rely heavily on digital queries. This is a signature feature of his approach. Another novel feature is that he draws on the high-quality databasis of ARTFL's FRANTEXT, and not only on Google scans. The digital searches serve to identify large-scale trends and to extend the corpus of texts beyond canonical authors. This is illustrated by n-grams showing long-term sequences of human-rights terms, which are used to corroborate some quantifying claims. However, the narrative is not reduced only to this. Some key texts from the history of political thought are analyzed too. For example, in the case of Spinoza Edelstein analyzes the whole texts, and not only occurrences of isolated terms. ${ }^{22}$ This does yield interesting results; in this case it is a correction of Jonathan Israel's democratic interpretation of Spinoza. In a similar fashion, he provides a textual analysis of John Locke's Second Treatise, which corrects

20 See Lynn Hunt, Inventing Human Rights: A History, New York 2007.

21 A similar claim has been raised in Vincent MARCAGgi, Les origins de la Déclaration des droits de l'homme de 1789, Paris 1912.

22 D. Edelstein, On the Spirit, pp. 47-49. 
the traditional libertarian conclusions. ${ }^{23}$ In addition to that, legal cultures of English common law and French interest in Roman law are also discussed. This is a method combining quantifying sequences of isolated notions with textual analyses.

The slim book, written by a respected American author, does provide a way out of the prevailing simplistic interpretations and therefore it should also interest European historians. For this reason, I felt that this forum could be a start for a dialogue between US historiography and Europe on the issue of general histories of universal human rights. The starting point could be the "genealogical" approach which actually provides very weak limits on the authorial handling of facts. The geographical and intellectual legal contexts of early modern human rights could certainly be more fully developed.

For this reason, I have addressed several internationally renowned French scholars who will comment on some aspects of Dan Edelstein's narrative. Thérence Carvalho, who has just finished a huge monograph on physiocracy, will comment on the role of the physiocratic school in the advancement of human rights. ${ }^{24}$ Emanuelle de Champs, who is an expert on Jeremy Bentham, will comment on the exchange of ideas on law between England and France. ${ }^{25}$ Olivier Grenouilleau, who has written extensively on the slave trade, will comment on the background to the French debate on abolitionism. ${ }^{26} \mathrm{He}$ has in fact just published a challenging monograph on the abolition debate. ${ }^{27}$ Finally, Ivo Cerman will comment on the significance or irrelevance of natural law for the invention of universal human rights. The forum will conclude with responses provided by Dan Edelstein.

23 Iвidem, pp. 50-55.

24 Thérence Carvalho, La physiocratie dans l'Europe des Lumières. Circulation et réception d'un modèle de réforme de l'ordre juridique et sociale, Paris 2020. The work elaborates the achievement of his tutor Anthony Mergey, L'état des physiocrates: autorité et decentralization, Aix-en-Provence 2010.

25 See Emanuelle De Champs, Enlightenment and Utility. Bentham in French, Bentham in France, Cambridge 2015, EAdEM - Jean Pierre Cléro (edd.), Bentham et la France: fortune et infortune de l'utilitarisme, Oxford 2009.

26 See Olivier Grenoullleau, Les traites négrières. Essai d'histoire globale, Paris 2004.

27 IDEM, La révolution abolitioniste, Paris 2017. 
Ivo Cerman

\section{Beyond a Genealogy of Human Rights}

Introduction to a Discussion Forum

\section{Abstract}

The introductory essay explains the motivation for this discussion forum. After the success of Samuel Moyn's slim book on Utopian human rights, the American historians of human rights began to turn a blind eye to the whole period before the 1970s, including the Age of Enlightenment. The focus is now more on persons and events of the Utopian decade, and not on the history of human rights. „On the Spirit of Rights“ is a recent monograph by an influential American historian, which may help reverse the tide. There follows a brief summary of the argument of the book and an introduction to the participants in the discussion. In his discussion of enlightenment authors, Edelstein focuses on the question whether they recognized natural rights after the social contract. He calls such an approach the „preservation regime“ and identifies the physiocrats as authors of such a solution.

KEY WORDS:

historiography; human rights; Dan Edelstein; contemporary history; Enlightenment 